\title{
The Combination of Passiflora alata and Valeriana officinalis on Memory Tasks in Mice: Comparison with Diazepam
}

\author{
Helvo Slomp Junior ${ }^{1,2}$, Gerusa Seniski ${ }^{2}$, Cláudio da Cunha $^{2}$, Elizabeth Aparecida Audi ${ }^{3}$ \\ and Roberto Andreatini ${ }^{2 *}$ \\ ${ }^{I}$ Departamento de Saúde Comunitária; Universidade Federal do Paraná; Curitiba - PR - Brasil. ${ }^{2}$ Laboratório de \\ Fisiologia e Farmacologia do Sistema Nervoso Central; Departamento de Farmacologia; Universidade Federal do \\ Paraná; Curitiba - PR - Brasil. ${ }^{3}$ Departamento de Farmacologia; Universidade de Maringá; Maringá - PR - Brasil
}

\begin{abstract}
The effect of a compound combining Valeriana officinalis and Passiflora alata extracts was tested on two mouse memory models: habituation and step-through inhibitory avoidance. Diazepam (1.0 and $2.5 \mathrm{mg} / \mathrm{kg}$ ) was used as a positive control. Acute diazepam $(2.5 \mathrm{mg} / \mathrm{kg})$ before training impaired the habituation and performance in the inhibitory avoidance. On the other hand, acute phytotherapeutic compound (40-160 $\mathrm{mg} / \mathrm{kg})$, also before the training session, did not alter mouse behavior in these models. Repeated (15 days) treatment with the compound also did not impair the habituation. At the doses used, no locomotor effect was found. Taken together, the results suggest that, contrary to diazepam, the anxiolytic Valeriana officinalis and Passiflora alata compound did not induce amnesia.
\end{abstract}

Key words: amnesic, benzodiazepine, memory, mice, phytotherapy

\section{INTRODUCTION}

Generalized Anxiety Disorder (GAD) is a chronic and prevalent mental disorder that causes high morbidity and personal suffering. Benzodiazepines are the most frequently used drugs to treat GAD, although buspirone and antidepressants are also employed (Andreatini et al., 2001). While these drugs are effective, they present several problems, such as the amnesic effect of benzodiazepines (Izquierdo and Medina, 2001) and some tricyclic antidepressants (Amado-Boccara et al, 1995). Moreover, there is only a partial tolerance to the deleterious effect of benzodiazepines even with chronic use (Gorenstein et al., 1995).

Phytomedicines are an interesting alternative to synthetic drugs for therapy (e.g. Goluart et al., 2005) and they offer the potential for the development of distinctly new drugs (Calixto, 2000; Carlini, 2003). Among the several phytomedicines studied as potential anxiolytics, Piper methysticum, Passiflora incarnata, Passiflora actinia, Passiflora alata and Valeriana officinalis showed some anxiolytic effect (Oga et al., 1984; Wong et al., 1998; Akhondzadeh et al., 2001; Dhawan et al., 2001a; Dhawan et al., 2001b; Andreatini et al., 2002; Dhawan et al., 2004; Santos et al., 2006). More specifically, a plant extract combination containing Passiflora incarnata and Valeriana officinalis showed an anxiolytic clinical effect (Bourin et al., 1997). A combination of a hydroethanolic extract of Passiflora alata Dryander and Valeriana officinallis L. (CPV, $20 \mathrm{mg} / \mathrm{kg}$ ) showed an anxiolytic effect in the elevated plus-maze after repeated (15 days), but not acute, treatment

\footnotetext{
*Author for correspondence: randreatini@ufpr.br
} 
(Otobone et al., 2005). Recently, Tabach et al. (2009) also found an anxiolytic-like effect with a phytotherapeutic product containing Passifora incarnata L., Valeriana officinalis L., and Crataegus oxycantha L., a result that reinforced the putative anxiolytic-like effect of CPV. However, to improve the drug armamentarium for the treatment of anxiety, besides an anxiolytic effect a new drug should also be devoid of some adverse effects of the standard anxiolytics, such as memory impairment (Andreatini et al., 2001).

Habituation can be defined as a decrease of a behavioral response after a repeated exposure (Platel and Porsolt, 1982). Habituation can be measured as the difference between the exploratory activity observed in two serial experimental sessions in the same apparatus (Platel and Porsolt, 1982; Ukai et al., 1994). The increase in the horizontal activity (ambulation) in the second session is a better measure of memory than the vertical activity, e.g., rearing (Ukai et al., 1994). Inhibitory avoidance is a procedure based on the association of a behavior with an unpleasant event leading to a hesitation to exhibit this behavior on the next occasion. In the step-through procedure, the latency to enter the dark compartment to avoid a footshock is measured (Sahgal, 1993).

In animal models of memory, the time of drug administration is an important experimental variable. Although the post-training administration can be more clearly interpreted in terms of impairment or improvement of memory consolidation, avoiding a change in the alertness or motivation (Platel and Porsolt, 1982), in the clinical setting, the anxiolytic drugs are used to exert their effect during the day. Besides, the amnesic effect of benzodiazepine anxiolytics is observed with pre-training, but not post-training administration (Izquierdo and Medina, 2001). In this way, pre-training drug administration models the clinical situation more closely than posttraining administration. Therefore, with the aim to study the effect of CPV on memory in a similar pattern to the clinical use of an anxiolytic drug, the animal performance after the drug administration was evaluated in this work.

The aim of the present study was to determine whether the CPV had a benzodiazepine (diazepam)-like amnesic effect using two mouse models: the habituation to a new environment, and the inhibitory avoidance.

\section{MATERIAL AND METHODS}

\section{Animals}

Animals were adult male Swiss mice (60-90 days old) from the breeding colony, weighing between 20 and $25 \mathrm{~g}$. They were housed in polypropylene cages with wood shavings as bedding, under controlled conditions of light $(12 \mathrm{~h}$ light-dark cycle, lights on at 7:00 a.m.) and temperature (22 $\pm 2{ }^{\circ} \mathrm{C}$ ). The animals had free access to water and food throughout the experiment.

\section{Drugs and Treatment}

Diazepam (Cristália, Brazil) at 1.0 and $2.5 \mathrm{mg} / \mathrm{kg}$ (i.p., at constant volume of $10 \mathrm{ml} / \mathrm{kg}$ ) was used as positive control. The phytotherapeutic compound (CPV) consisted of a combination of hydroethanolic extract from Passiflora alata Dryander leaves and Valeriana officinalis L. roots $(1.7 \mathrm{ml} / 1.0 \mathrm{ml}$ respectively) and had a final composition of $65 \%$ ethanol and $9.3 \%$ dry residue. This combination was standardized at $0.044 \%$ of valerenic acid and 0.1062 of vitexina (Audi et al., 2005). The dry residue (Herbarium Laboratório Botânico) was re-suspended in deionized water immediately before the experiments. CPV and its vehicle were administered p.o. at a constant volume of $10 \mathrm{ml} / \mathrm{kg}$. The vehicle of the diazepam and CPV were used as negative controls.

\section{Apparatus}

Spontaneous Locomotor Activity Chamber

The locomotor activity of each animal was measured with photocell-equipped activity chambers (Plexiglas cages, $40 \times 25 \times 20 \mathrm{~cm}$ ), with a grid floor made of stainless steels bars (spaced $1.0 \mathrm{~cm}$ apart) and provided with three photocells (spaced $10 \mathrm{~cm}$ apart and at a height of $1.5 \mathrm{~cm}$ ). The luminosity of the chamber during the experiments was 0.57 lux (Camarini et al., 1995).

\section{Inhibitory Avoidance}

The inhibitory avoidance test apparatus was an automated shuttle box (GEMINI Avoidance System, San Diego Instruments, San Diego, CA) with a dark glass front and a floor made of parallel 2-mm diameter stainless-steel bars spaced 8-mm apart. The box $(23 \times 50 \times 23 \mathrm{~cm})$ was divided into an illuminated compartment and a dark compartment of the same size separated by a wall with a guillotine door $(6 \times 9 \times 6 \mathrm{~cm})$. Plexiglas transparent sheets for mice were used to reduce the 
size of the illuminated compartment to $12.5 \times 14.5$ $\mathrm{x} 7.0 \mathrm{~cm}$.

\section{Procedure \\ Habituation}

The animals were submitted to two sessions in the activity chamber $24 \mathrm{~h}$ apart (training and test, respectively). During each session, the animal was allowed to freely explore the chamber for $5 \mathrm{~min}$ and the number of times the animal interrupted the light beams was computed at 2 and $5 \mathrm{~min}$. The decrease in these exploration scores (number of beam interruptions) between the training and test sessions was taken as a measure of habituation (Platel and Porsolt, 1982).

\section{Inhibitory avoidance}

In the training session, each mouse was placed individually in the illuminated compartment facing the closed door. After $10 \mathrm{~s}$ of adaptation, the light was turned on, the door was opened and the latency to enter the dark compartment was recorded. After entering the dark compartment, the animal received an unavoidable foot shock (0.5$\mathrm{mA}, 1 \mathrm{~s})$. Then the animal was immediately withdrawn from the apparatus and returned to its home cage. No animal took more than $120 \mathrm{~s}$ to enter the dark compartment in the training session. The test session, carried out $24 \mathrm{~h}$ later, was similar to the training session, except that the animal did not receive a foot shock and a maximum latency of $300 \mathrm{~s}$ was employed. The latency of entry into the dark compartment in the test session was taken as a measure of retention (Fujishiro et al., 2002).

\section{Statistical Analysis}

Inhibitory avoidance test data were analyzed statistically by one-way ANOVA, followed by the Tukey Honest test when appropriate. The habituation was assessed by comparing session 1 behavior with session 2 behavior within the group using the two-tailed Student t test for repeated measures [15].

The locomotor effect of drugs was assessed by comparison among the treatments in session 1 of habituation and inhibitory avoidance (one-way ANOVA followed by the Tukey Honest test). The level of significance was set at $p<0.05$. All values are reported as mean \pm SEM.

\section{RESULTS}

\section{Habituation}

As expected, the higher dose of diazepam (2.5 $\mathrm{mg} / \mathrm{kg}$ ) impaired the habituation of mice (Fig. 1) since no inter-session decrement was seen at $2(\mathrm{t}=$ $0.04 ; \mathrm{df}=10 ; \mathrm{p}>0.05)$ and $5 \min (\mathrm{t}=-0.02 ; \mathrm{df}=$ $10 ; \mathrm{p}>0.05)$. On the other hand, the lower dose of diazepam $(1.0 \mathrm{mg} / \mathrm{kg})$ and the vehicle caused a marked decrease in the locomotor activity between the training and test sessions (habituation) at 2 (diazepam 1.0: $\mathrm{t}=8.03 ; \mathrm{df}=9 ; \mathrm{p}<0.001$; vehicle $\mathrm{t}$ $=4.67 ; \mathrm{df}=9 ; \mathrm{p}<0.05)$ and $5 \mathrm{~min}$ (diazepam 1.0: $\mathrm{t}$ $=3.06 ; \mathrm{df}=9 ; \mathrm{p}<0.05$; vehicle: $\mathrm{t}=2.86 ; \mathrm{df}=9$; $\mathrm{p}<0.05)$.

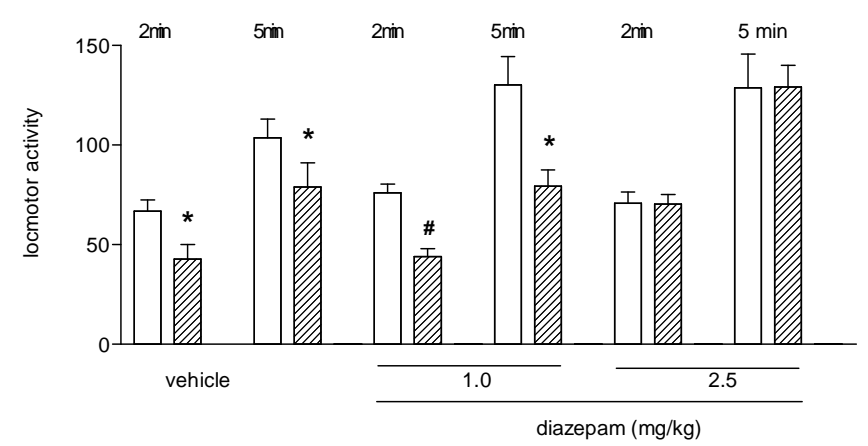

Figure 1 - Effects of diazepam (and its vehicle, i.p., $30 \mathrm{~min}$ before training) on habituation of spontaneous locomotor activity in mice between training session (white bars) and test session (hatched bars). Interval between sessions was $24 \mathrm{~h}$. The results are expressed as mean \pm SEM of the number of beam interruptions recorded at 2 and $5 \mathrm{~min}$ of each session ( $\mathrm{n}=10 \mathrm{mice} /$ group). $* \mathrm{p}<0.05$ vs. training session of the same group; $\# \mathrm{p}<0.01$ vs training session of the same group (Student $t$ test for repeated measures). 
A

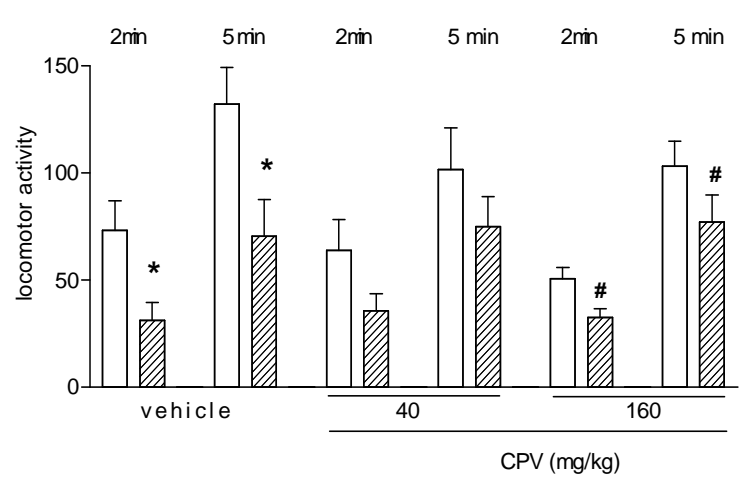

B

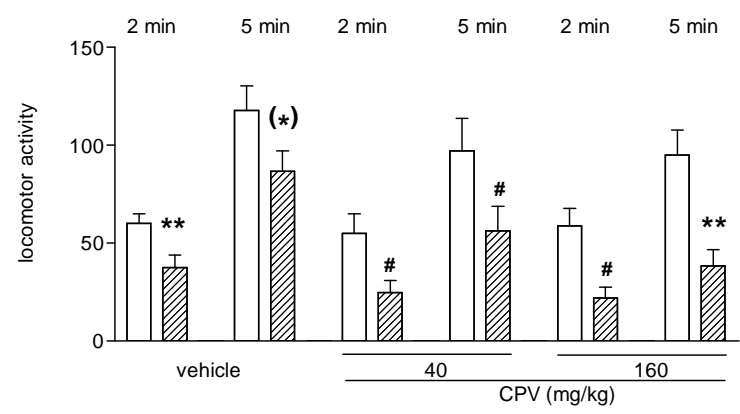

Figure 2 - Effects of Passiflora-Valeriana extract combination (CPV), and its vehicle (both p.o, $30 \mathrm{~min}$ before training), on habituation of spontaneous locomotor activity in mice between training session (white bars) and test session (hatched bars). Interval between sessions was $24 \mathrm{~h}$. Upper panel (A): acute treatment ( $\mathrm{n}=10-11$ mice/ group); lower panel (B): chronic (15 days) treatment ( $\mathrm{n}=8-12$ mice/ group). The results are expressed as mean \pm SEM of the number of beam interruptions recorded at 2 and 5 min of each session. $(*) 0.06>p>0.05 \mathrm{Vs}$ training session of the same group; \# $\mathrm{p}<0.01 \mathrm{Vs}$ training session of the same group; ${ }^{* *} \mathrm{p}<0.001$ vs. training session of the same group (Student $\mathrm{t}$ test for repeated measures

In the acute CPV experiment, the vehicle-treated mice showed habituation at $2(\mathrm{t}=3.7$; $\mathrm{df}=9$; $\mathrm{p}<0.001)$ and $5 \min (\mathrm{t}=5.41 ; \mathrm{df}=9 ; \mathrm{p}<0.001)$. CPV, however, gave contradictory results: although the higher dose $(160 \mathrm{mg} / \mathrm{kg})$ presented habituation at $2(\mathrm{t}=2.97 ; \mathrm{df}=10 ; \mathrm{p}<0.05)$ and 5 $\min (t=2.49 ; \mathrm{df}=10 ; \mathrm{p}<0.05)$, the lower dose $(40$ $\mathrm{mg} / \mathrm{kg})$ did not show any difference at $2(\mathrm{t}=1.87$; $\mathrm{df}=10 ; \mathrm{p}>0.05)$ or $5 \mathrm{~min}(\mathrm{t}=1.67 ; \mathrm{df}=10$; $\mathrm{p}>0.05$ ). (Fig. 2A).

No impairment of habituation was seen after repeated treatment (15 days) with CPV (Fig. 2B). There was a significant difference between the training and test session in mice treated with vehicle $(2$ min: $\mathrm{t}=5.26 ; \mathrm{df}=8 ; \mathrm{p}<0.001), \mathrm{CPV} 40$ $\mathrm{mg} / \mathrm{kg}(2 \mathrm{~min}: \mathrm{t}=3.10 ; \mathrm{df}=7 ; \mathrm{p}<0.05 ; 5 \mathrm{~min}: \mathrm{t}=$ 3.17; $\mathrm{df}=7 ; \mathrm{p}<0.05)$, and CPV $160 \mathrm{mg} / \mathrm{kg}(2 \mathrm{~min}$ : $\mathrm{t}=4.32 ; \mathrm{df}=11 ; \mathrm{p}<0.05 ; 5$ min: $\mathrm{t}=4.67 ; \mathrm{df}=11$; $\mathrm{p}<0.001)$. The 5 min measure of vehicle-treated mice did not reach the significance level in training vs. test comparison $(\mathrm{t}=2.19 ; \mathrm{df}=8$; $\mathrm{p}=0.059$ ).

\section{Inhibitory Avoidance}

As expected, diazepam impaired memory in the inhibitory avoidance task $\left(\mathrm{F}_{2,39}=3.59 ; \mathrm{p}<0.05\right.$; Fig. 3 , upper panel). The higher diazepam dose (2.5 $\mathrm{mg} / \mathrm{kg}$ ), administered before the training session, significantly reduced the latency to enter the dark compartment in the test session ( $p<0.05$, Tukey). On the other hand, neither dose of the CPV (40$160 \mathrm{mg} / \mathrm{kg}$ ) changed the latency to enter the dark compartment in the test session $\left(\mathrm{F}_{2,33}=1.65\right.$; p>0.05; Fig. 3, lower panel). No effect was seen in 
the training session of diazepam $\left(\mathrm{F}_{2,39}=1.00\right.$; $\mathrm{p}>0.05$; Fig. 3, upper panel) or $\mathrm{CPV}\left(\mathrm{F}_{2,33}=0.01\right.$; p>0.05; Fig. 3, lower panel).

\section{Locomotor activity}

Since diazepam and CPV did not change the number of beam interruptions in the training session for habituation or escape latency in the training session for inhibitory avoidance, it was concluded that these compounds, at the doses used here, did not alter locomotor activity.

\section{DISCUSSION}

The main result of the present study was that the phytotherapeutic compound of $V$ officinalis and $P$ alata did not present the memory impairment exhibited by diazepam in animal models. Thus, while diazepam impaired the habituation and performance in the step-through inhibitory avoidance, indicating an amnesic effect, the CPV (acute or repeated) did not alter the behavior on these learning tasks. However, the data obtained here do present some problems.
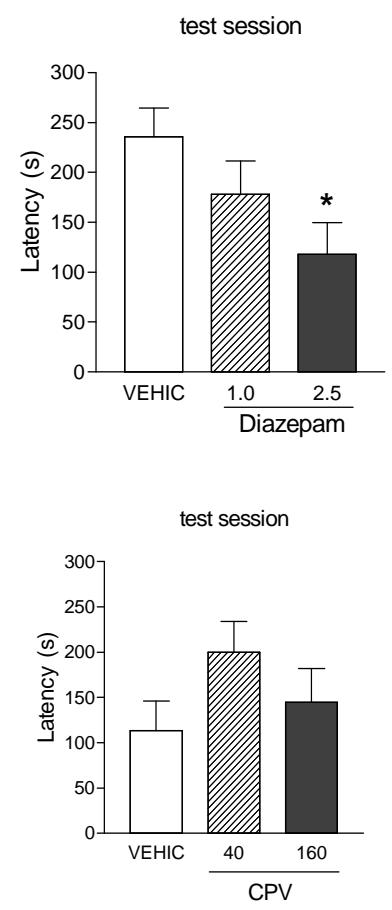

Figure 3 - The effect of diazepam and Passiflora-Valeriana extract combination on the Inhibitory Avoidance test in mice. Upper panel (A): diazepam or its vehicle (VEHIC), i.p., $n=7$ 11 mice/ group; lower panel (B) the Passiflora-Valeriana extract combination (CPV) or its vehicle (VEHIC), p.o., $\mathrm{n}=11-13$ mice/ group. Step-through latencies were measured in seconds, in the training (left) and test (right) sessions $24 \mathrm{~h}$ apart. Drug administration took place 30 min before training. Data represents mean \pm SEM. * p < 0.05 compared with vehicle; ANOVA followed by Tukey test).

The results for the acute effect of CPV could be considered contradictory since the mice treated with the CPV lower dose did not show any habituation, while this was observed in the mice treated with the CPV higher dose. This could indicate a U-shaped dose-response curve for the CPV. However, the CPV did not impair the performance in the test session for inhibitory avoidance. Thus, in order to clarify this point, the CPV data was further explored using the habituation data (training score minus test score) analysis (Kopf and Baratti, 1996). Using this methodology, no significant differences in the habituation were found among the treatments in acute and chronic paradigms at $2(\mathrm{~F} 2,29=1.0$; $\mathrm{p}>0.05)$ or $5(\mathrm{~F} 2,29=2.4 ; \mathrm{p}>0.05)$ min. Thus, it 
was concluded that memory impairment in this task was absent after acute CPV treatment.

Other point that deserved the discussion was that, in the test session in the inhibitory avoidance, the values for diazepam (Fig. 3A right) and CPV 160 (3B right) were similar, which could cause some doubt about the absence of impairment of CPV at this dose. However, compared to vehicle groups, while diazepam impaired the performance, CPV had no effect. This stressed the importance of concurrent control animals.

It should be stressed that these effects were found without any effect on locomotor activity. The absence of locomotor impairment at the dose used here was in accordance with the data obtained with the rats submitted to the open-field test in which impairment was seen only at doses above 300 $\mathrm{mg} / \mathrm{kg}$ p.o. (Audi et al., 2005). The anxiolytic effect in the elevated plus-maze was seen after repeated (14 days) treatment with CPV $20 \mathrm{mg} / \mathrm{mg}$ (Audi et al., 2005), a dose much lower than the sedative dose, which suggested a wide dose range for the CPV anxiolytic effect.

Although there are studies indicating an anxiolytic effect of $V$ officinalis and Passiflora (Akhondzadeh et al., 2001; Dhawan et al., 2001a; Dhawan et al., 2001b; Andreatini et al., 2002; Dhawan et al., 2004), data for a possible memory effect are scarce. Moreover, some neurochemical effects have been associated with this anxiolytic effect. The valerian extract or some of its constituents, such as valerenic acid, exhibits some actions that, like the benzodiazepines, increase the GABA transmission (direct action on $\mathrm{GABA}_{\mathrm{A}}$ receptors, decreased GABA metabolism or reuptake), which may contribute to its anxiolytic effect (Wong et al., 1998; Houghton, 1999; Ortiz et al., 1999). However, in the present study, the $\mathrm{CPV}$ did not induce any memory impairment, which was contrary to expectations for this GABA enhancement action of valerian. On the other hand, the absence of amnesic effect of CPV was in accordance with the literature with no reports of deleterious effects on cognition or psychomotor performance in the clinical studies with valerian or valepotriates (Andreatini et al., 2002; Kuhlman et al., 1999; Glass et al., 2003; Hallam et al., 2003; Gutierrez et al., 2004). To explain this paradox, it was postulated that the behavioral effect of the phytomedicines could be due to a synergistic interaction between its constituents (Della-Loggia et al., 1981; Williamson, 2001). Thus, it could be hypothesized that some other constituents of CPV could neutralize this deleterious effect on memory. Another possibility would be that the CPV acted selectively at GABA-A subtype, like alpha- 2 subunit, which would be associated to anxiolytic effect without memory impairment (Mohler et al., 2002).

Passiflora alata Dryander exerts an anxiolytic effect on performance in the elevated plus-maze (Petry et al., 2001), an effect that could be related to the presence of flavonoids, such as chrysin and apigenin (Paladini et al., 1999). This chemical group, chrysin and apigenin in particular, has a putative partial agonist action on the benzodiazepine receptor and exhibits an anxiolytic-like effect in animal models (Wolfman et al., 1994; Salgueiro et al., 1997; Paladini et al., 1999; Zanoli et al., 2000; Petry et al., 2001). It is interesting to note that the CPV profile (anxiolytic effect without memory impairment) is compatible with a partial agonist benzodiazepine action (Lader, 1995). This same behavioral profile was also found for chrysin and apigenin: an anxiolytic effect in the elevated plus-maze without impairment of the habituation and inhibitory avoidance (Wolfman et al., 1994; Salgueiro et al., 1997; Paladini et al., 1999). However, the anxiolytic effect of Passiflora incarnata was not due to any known phytoconstituents, including chrysin (Dhawan et al., 2004; Soulimani et al., 1997). In this line, it was interesting to note that the central nervous system effects of Passiflora incarnata was related to a tri-substituted benzoflavone moiety isolated from methanol extract of this plant (Dhawan et al., 2004).

Although the present results are mainly negative, their importance lies in differentiating the adverse profile of the putative anxiolytic compound from the standard anxiolytics benzodiazepines and, in the future, it may become a pharmacological alternative for the treatment of generalized anxiety disorder.

In conclusion, the acute and repeated administration of a compound combining $V$ officinalis and $P$ alata extracts did not appear to produce the memory impairment in the habituation and inhibitory avoidance in mice. Although these results suggested an absence of amnesic effect of the compound, the present data need to be confirmed in other animal memory tasks and by the clinical trials. 


\section{ACKNOWLEDGMENTS}

We thank Mrs. Silvia Cordazzo Genaro for her technical assistance. This study was partially supported by FUNPAR. The Passiflora-Valeriana extract combination was a kind gift of Herbarium Laboratory, Curitiba, Brazil. RA and $\mathrm{CC}$ are the recipients of Brazilian National Research Council $(\mathrm{CNPq})$ research fellowships.

\section{RESUMO}

Avaliou-se o efeito de um composto fitoterápico de Valeriana officinalis e Passiflora alata em dois modelos de memória em camundongos: habituação e esquiva inibitória tipo step-trough. Diazepam $(1,0$ e $2,5 \mathrm{mg} / \mathrm{kg})$ foi empregado como controle positivo. Agudamente, a administração de diazepam $(2,5 \mathrm{mg} / \mathrm{kg})$ antes do treino prejudicou o desempenho na habituação e na esquiva inibitória. Por outro lado, a administração aguda do composto fitoterápico $(40-160 \mathrm{mg} / \mathrm{kg}$ ) antes do treino não alterou o comportamento dos camundongos nestes modelos. Tratamento com o composto fitoterápico por 15 dias também não alterou o comportamento dos animais. Nas doses empregadas não se observou alteração da atividade motora. Os dados sugerem que, diverso do diazepam, este fitoterápico ansiolítico composto de Valeriana officinalis e Passiflora alata não causa amnésia.

\section{REFERENCES}

Akhondzadeh, S., Naghavi, H.R., Vazirian, M., Shayeganpour, A., Rashidi, H., Khani, M. (2001) Passionflower in the treatment of generalized anxiety: a pilot double-blind randomized controlled trial with oxazepam. J Clin Pharm Ther, 26, 363-367.

Amado-Boccara, I., Gougoulis, N., Poirier Littré, M.F., Galinowski, A., Lôo, H. (1995) Effects of antidepressants on cognitive functions: a review. Neurosci Biobehav Rev, 19(3), 479-493.

Andreatini, R., Sartori, V.A., Seabra, M.L.V., Leite, J.R. (2002) Effect of valepotriates (valerian extract) in generalized anxiety disorder: a randomized placebo-controlled pilot study. Phytother Res 16, 650-654.
Andreatini, R., Zorzetto, D., Boergnen-Lacerda, R. (2001) Tratamento farmacológico do transtorno de ansiedade generalizada: perspectivas futuras. [Pharmacological treatment of generalized anxiety disorder: future perspectives.] Rev Bras Psiq 23(4), 233-242.

Bourin, M., Bougerol, T., Guitton, B., Broutin, E. (1997) A combination of plant extracts in the treatment of outpatients with adjustment disorder with anxious mood: controlled study versus placebo. Fundam Clin Pharmacol 11, 127-132.

Calixto, J.B. (2000) Efficacy, safety, quality control, marketing and regulatory guidelines for herbal medicines (phytotherapeutic agents). Braz J Med Biol Res 33(2), 179 -189.

Camarini, R., Andreatini, R., Monteiro, M.G. (1995) Prolonged treatment with carbamazepine increases the stimulatory effects of ethanol in mice. Alcohol 12(4), 305-308.

Carlini, E.A. (2003) Plants and the central nervous system. Pharmacol Biochem Behav 75(3), 501-512.

Della-Loggia, R., Tubaro, A., Redaelli, C. (1981) Evaluation of the activity on the mouse CNS of several plant extracts and a combination of them. Riv Neurol 51(5), 297-310.

Dhawan, K., Dhawan, S., Sharma, A. (2004) Passiflora: a review update. J Ethnopharmacol 94, 1-23.

Dhawan, K., Kumar, S., Sharma, A. (2001b) Anxiolytic activity of aerial and underground parts of Passiflora incarnata. Fitoterapia 72, 922-926.

Dhawan, K., Kumar, S., Sharma, A. (2001a) Antianxiety studies on extracts of Passiflora incarnata Linneaus. J Ethnopharmacology 78, 165-170

dos Santos, K.C., Kurtz, S.M.T.F., Müller, S.D., Biavatti, M.W., Rúbia Maria Monteiro Weffort de Oliveira, R.M.M.W., Santos, C.A.M. (2006) Sedative and anxiolytic effects of methanolic extract from the leaves of Passiflora actinia. Braz. arch. biol. technol. 49(4), 565-573.

Fujishiro, J., Imanishi, T., Onozawa, K., Tsushima, M. (2002) Comparison of the anticholinergic effects of the serotonergic antidepressants,paroxetine, fluvoxamine and clomipramine. Eur J Pharmacol 454, 183-188.

Glass, J.R., Sproule, B.A., Hermann, N., Streiner, D., Busto, E.U. (2003) Acute pharmacological effects of temazepam, diphenhydramine, and valerian in healthy elderly subjects. J Clin Psychopharmacol 23, 260-8.

Gorenstein, C., Bernik, M.A., Pompéia, S., Marcourakis, T. (1995) Impairment of performance associated with long-term use of benzodiazepines. $J$ Psychopharmacol 9, 313-318. 
Goulart, Y.C.F, Sela, V.R., Obici, S., Martins, J.V.C., Otobone, F., Cortez, D.A. Audi, E.A. (2005) Evaluation of gastric anti-ulcer activity in a hydroethanolic extract from Kielmeyera coriacea Braz. arch. biol. technol. 48(1): 211-216.

Gutierrez, S., Ang-Lee, M.K., Walker, D.J., Zacny, J.P. (2004) Assessing subjective and psychomotor effects of the herbal medication valerian in healthy volunteers. Pharmacol Biochem Behav 78, 57-64.

Hallam, K.T., Olver, J.S., McGrath, C., Norman, T.R. (2003) Comparative cognitive and psychomotor effects of single doses of Valeriana officinalis and triazolam in healthy volunteers. Hum Psychopharmacol 18(8), 619-25.

Houghton, P.J. (1999) The scientific basis for the reputed activity of valerian. J Pharm Pharmacol 51, 505-12.

Izquierdo, I., Medina, J. H. (2001) GABA-A receptor modulation of memory: The role of endogenous benzodiazepines. Trends Pharmacol Sci 12, 260-265.

Kopf, S.R., Baratti, C.M. (1996) Effects of post-training administration of glucose on retention of a habituation response in mice: participation of a central cholinergic mechanism. Neurobiol Learn Mem 65, 253-260.

Kuhlman, J., Berger, W., Podzuweit, H., Schmidt, U. (1999) The influence of valerian treatment on "reaction time, alertness and concentration" in volunteers. Pharmacopsychiatry 32(6), 235-41.

Lader, M. (1995) Clinical pharmacology of anxiolytic drugs: past, present and future. In: GABA-A receptors and anxiety: from neurobiology to treatment. Biggio, G., Sanna, E., Costa, E. (eds.) Raven Press, New York, pp. 135-152.

Möhler, H., Fritschy, J. M., Rudolph, U. (2002) A new benzodiazepine pharmacology J. Pharmacol. Exp. Ther. 300(1), 2-8.

Oga, S., Freitas, P.C.D., Gomes da Silva, A.C., Hanada, S. (1984) Pharmacological trials of crude extract of Passiflora alata. Planta Med 50(4), 303-306.

Ortiz, J.G., Nieves-Natal, J., Chavez, P. (1999) Effects of Valeriana officinalis extracts on [H-3] flunitrazepam binding, synaptosomal [H-3] GABA uptake, and hippocampal [H-3] GABA release. Neurochem Res 24(11), 1373-1378.

Otobone, F.J., Martins, J.V.C. Trombelli, M.A., Andreatini, R. Audi, E.A. (2005) Anxiolytic and sedative effects of a combined extract of Passiflora alata Dryander and Valeriana officinalis L. in rats Acta Sci Health Sci 27(2), 145-150

Paladini, A.C., Marder, M., Viola, H., Wolfman, C., Wasowski, C., Medina, J.H. (1999) Flavonoids and the central nervous system: from forgotten factors to potent anxiolytic compounds. J. Pharm Pharmacol 51, 519-26.
Petry, R.D., Reginatto, F., De-Paris, F., Gosmann, G., Salgueiro, J.B., Quevedo, J., Kapczinski, F., Ortega, G.G., Schenkel, E.P. (2001) Comparative pharmacological study of hydroethanol extracts of Passiflora alata and Passiflora edulis leaves. Phytotherapy Research 15, 162 - 164.

Platel, A., Porsolt, R.D. (1982) Habituation of exploratory activity in mice: a screening test for memory enhancing drugs. Psychopharmacology 78, 346-352.

Sahgal A. (1993) Passive avoidance procedures. In: Behavioural neuroscience: a practical approach. Sahgal, A. (ed.) Oxford University Press, Oxford, pp. 49-56.

Salgueiro, J.B., Ardenghi, P., Dias, M., Ferreira, M.B.C., Izquierdo, I., Medina, J.H. (1997) Anxiolytic natural and synthetic flavonoid ligands of the central benzodiazepine receptor have no effect on memory tasks in rats. Pharmacol Biochem Behav 58(4), 88791.

Soulimani, R., Younos, C., Jarmouni, S., Bousta, D., Misslin, R., Moutier, F. (1997) Behavioural effects of Passiflora incarnata L. and its indole alkaloid and flavonoid derivates and maltol in the mouse. $J$ Ethnopharmacol 57, 11-20.

Tabach, T. R., Mattei, R., Carlini, E.L.A.(2009) Pharmacological evaluation of a phytotherapeutic product - CPV (dry extract of Crataegus oxyacantha L., Passiflora incarnata L. and Valeriana officinalis L.) in laboratory animals. Rev. bras. farmacogn 19(1B), 255-260.

Ukai, M., Kobayashi, T., Kameyama, T. (1994) Effects of several amnesic drugs on the habituation of exploratory activity in mice as indexed by horizontal and vertical activities. Gen Pharmacol 25(1), 179185.

Williamson, E.M. (2001) Synergy and other interactions in phytomedicine. Phytomedicine 8, 401409.

Wolfman, C., Viola, H., Paladini, A., Dajas, F., Medina, J.H. (1994) Possible anxiolytic effects of chrysin, a central benzodiazepine receptor ligand isolated from Passiflora coerulea. Pharmacol Biochem Behav 47, $1-4$.

Wong, A.H., Smith, M., Boon, H.S. (1998) Herbal remedies in psychiatric practice. Arch Gen Psychiatry 55(11), 1033-1044.

Zanoli, P., Avallone, R., Baraldi, M. (2000) Behavioral characterization of the flavonoids apigenin and chrysin. Fitoterapia 71(supp. 1), S117-S123.

Received: March 24, 2009; Revised: October 08, 2009; Accepted: July 06, 2010. 